\title{
Pengaruh PMDN, PMA dan Belanja Daerah Jawa Timur Terhadap Pertumbuhan Ekonomi di Kota Surabaya dan Kabupaten Banyuwangi
}

\author{
Hendry Cahyono ${ }^{1, *}$, Siska Anggraini Putri ${ }^{2}$ \\ ${ }^{1,2}$ Fakultas Ekonomi, Universitas Negeri Surabaya
}

\section{Informasi Artikel}

Sejarah artikel:

Diterima Januari 2017

Disetujui Maert 2017

Dipublikasikan Maret 2017

\section{Keywords:}

Domestic Investment,

Foreign Investment,

Regional Spending,

Economic Growth

\begin{abstract}
A BS TR ACT
This study aims to determine the effect of domestic investment, FDI and shopping area of East Java on economic growth in the Surabaya and Banyuwangi in 2001 until 2014. In order to prove the hypothesis of the study used econometric models with panel data regression methods. From the analysis it can be concluded that the variable domestic and foreign investments in East Java has no effect on economic growth in the city of Surabaya and Banyuwangi in 2001 until 2014, with a probability of domestic investment of 0.1386 and probability of FDI by 0.6313 with a significance level of 5\%. While variable shopping areas affect economic growth in East Java in Surabaya and Banyuwangi in 2001 to 2014, with probability equal to 0.0042 .
\end{abstract}




\section{Pendahuluan}

Pertumbuhan ekonomi adalah acuan untuk mengukur prestasi dari perkembangan perekonomian dari suatu periode ke periode berikutnya. Pembangunan daerah merupakan bagian integral dari pembangunan nasional yang dilaksanakan berdasarkan prinsip otonomi daerah.Tugas meningkatkan kesejahteraan bukan hanya kewajiban pemerintah, tetapi juga seluruh komponen masyarakat. Oleh karena itu pemerintah harus mampu memberdayakan seluruh komponen masyarakat, khususnya sektor swasta, untuk berperan lebih besar dalam meningkatkan kesejahteraan masyarakat. Dengan demikian, pertumbuhan ekonomi yang lebih adil, dan merata akan dapat dicapai dengan lebih baik dan cepat. Pemerintahan desentralisasi mulai dipraktekkan ketika diberlakukannya Undang-Undang Nomor 22 Tahun 1999 tentang Pemerintahan Daerah dan resmi dimulai sejak tanggal 1 Januari 2001. Kewenangan daerah kabupaten/kota dalam mengatur otonomi daerahnya mulai memegang peranan yang sangat penting. Pelaksanaan desentralisasi fiskal di Indonesia ditunjuk untuk menciptakan aspek kemandirian di daerah dengan prinsip otonomi daerah.

Provinsi Jawa Timur merupakan salah satu provinsi di Indonesia yang perekonomiannya baik. Hal itu dapat terlihat dari presentase pertumbuhan ekonomi Jawa Timur yang tinggi. Pertumbuhan Ekonomi Jawa Timur selama kurun waktu 2001-2015 mengalami pertumbuhan ratarata $5.36 \%$, di atas pertumbuhan ekonomi nasional yang rata-rata nya hanya $4,86 \%$

- Dalam teori ekonomi makro, dari sisi pengeluaran, pendapatan regional bruto adalah penjumlahan dari berbagai variabel termasuk di dalamnya adalah investasi. Investasi sendiri dipengaruhi oleh investasi asing dan domestik. Investasi dari sektor swasta dapat berasal dari dalam negeri maupun luar negeri (asing). Investasi merupakan salah satu variabel yang mam- pu mendongkrak perekonomian suatu daerah. Investasi bisa berupa penanaman modal untuk membuka usaha baru, memperluas usaha atau menambah kapasitas serta menambah jumlah aktivitas barang dan jasa yang akan menyerap banyak tenaga kerja serta menambah peningkatan belanja dan pendapatan masyarakat.

Investasi merupakan salah satu variabel yang mampu mendongkrak perekonomian suatu daerah. Investasi bisa berupa penanaman modal untuk membuka usaha baru, memperluas usaha atau menambah kapasitas serta menambah jumlah aktivitas barang dan jasa yang akan menyerap banyak tenaga kerja serta menambah peningkatan belanja dan pendapatan masyarakat. Diharapkan dengan berdirinya perindustrian di kawasan Jawa Timur dan disertai dengan penyediaan sarana dan prasarana yang memadai akan membawa dampak terhadap penyerapan tenaga kerja baik terdidik, tenaga kerja terlatih maupun tenaga kerja kasar. Sehingga investasi akan mendorong peningkatan pendapatan perkapita penduduk daerah. Pertumbuhan pendapatan perkapita menjadikan masyarakat tidak lagi bisa memenuhi kebutuhan pokok sehari-hari saja, namun kebutuhan sekunder maupun tersier dapat dipenuhi. Hal inilah yang akan memicu berkembangnya berbagai aktivitas perekonomian di daerah.

Pertumbuhan domestik regional bruto (PDRB), sebagai tolok ukur pertumbuhan suatu ekonomi regional tidak bisa lepas dari peran pengeluaran pemerintah di sektor layanan publik. Pengeluaran pemerintah daerah diukur dari total belanja rutin dan belanja pembangunan yang dialokasikan dalam anggaran daerah. Semakin besar pengeluaran pemerintah daerah yang produktif maka semakin memperbesar tingkat perekonomian disuatu daerah. Dalam hal ini peran pemerintah sangat diperlukan dalam mengatur perekonomian. Salah satu peran pemerintah dalam 
mengatur perekonomian adalah dengan menerapkan kebijakan fiskal dengan mengalokasikan pengeluaran untuk membangun saranan dan prasarana yang berguna untuk pembangunan. Pengeluaran pemerintah berkaitan erat dengan APBD (Anggaran Pendapatan Belanja Daerah) karena secara langsung akan mempengaruhi penerimaan daerah dan pembiayaanpembiayaan daerah, sehingga akan mempengaruhi pertumbuhan ekonomi secara langsung.

Dari paparan tersebut penulis tertarik untuk melakukan penelitian dengan judul "Pengaruh PMDN, PMA dan Belanja Daerah Jawa Timur terhadap Pertumbuhan Ekonomi di Kota Surabaya dan Kabupaten Banyuwangi". Dari latar belakang yang telah diuraikan dapat dirumuskan beberapa permasalahan sebagai berikut (1) Bagaimana pengaruh belanja daerah terhadap pertumbuhan ekonomi di Jawa Timur?; (2) Bagaimana pengaruh PMDN (Penanaman Modal Dalam Negeri) terhadap pertumbuhan ekonomi di Jawa Timur?; (3) Bagaimana pengaruh belanja daerah dan PMDN (Penanaman Modal Dalam Negeri) secara bersama terhadap pertumbuhan ekonomi di Jawa Timur?

Penelitian ini bertujuan untuk (1) Untuk mengidentifikasi pengaruh belanja daerah terhadap pertumbuhan ekonomi di Jawa Timur; (2) Untuk mengidentifikasi pengaruh PMDN terhadap pertumbuhan ekonomi di Jawa Timur; (3) Bagaimana pengaruh belanja daerah dan PMDN (Penanaman Modal Dalam Negeri) secara bersama terhadap pertumbuhan ekonomi di Jawa Timur.

\section{Pertumbuhan Ekonomi}

Menurut Mankiw (2003) menyatakan bahwa pertumbuhan ekonomi menunjukkan sejauh mana aktivitas perekonomian akan menghasilkan tambahan pendapatan masyarakat pada suatu periode tertentu. Karena pada dasarnya aktivitas perekonomian adalah suatu proses penggunaan faktor-faktor produksi untuk menghasilkan output, maka proses ini pada gilirannya akan menghasilkan suatu aliran balas jasa terhadap faktor produksi yang dimiliki masyarakat.

\section{Investasi}

Investasi merupakan suatu faktor krusial bagi kelangsungan proses pembangunan ekonomi (sustainable development) atau pertumbuhan ekonomi jangka panjang, peningkatan output dan pengurangan kemiskinan. Hal ini dikarenakan investasi mampu memberikan sumbangan modal atau kapital dalam proses produksi yang selanjutnya akan meningkatkan kapasitas produksi nasional. Pertambahan barang modal sebagai akibat investasi akan menambahkan kapasitas memproduksi di masa depan dan perkembangan ini akan menstimulir pertambahan produksi nasional dan kesempatan kerja (Sukirno, 2007).

\section{Penanaman Modal Dalam Negeri (Pmdn)} Dalam Undang-Undang no 6 tahun 1968 dan Undang-Undang nomor 12 tahun 1970 tentang Penanaman Modal Dalam Negeri (PMDN/ Undang-undang ini menjelaskan bahwa "modal dalam negeri" adalah : bagian dari kekayaan masyarakat Indonesia termasuk hak-hak dan bendabenda, baik yang dimiliki Negara maupun swasta asing yang berdomosili di Indonesia yang disisihkan atau disediakan guna menjalankan suatu usaha sepanjang modal tersebut tidak diatur oleh ketentuanketentuan pasal 2 UU No. 12 tahun 1970 tentang penanaman modal asing. Pihak swasta yang memiliki modal dalam negeri tersebut dalam ayat 1 pasal ini dapat terdiri atas perorangan dan/ atau badan hukum yang didirikan berdasarkan hukum yang berlaku di Indonesia. Kemudian dalam Pasal 2 disebutkan bahwa, yang dimaksud dalam Undang-Undang ini dengan "Penanaman Modal Dalam Negeri" ialah penggunaan daripada kekayaan seperti tersebut 
dalam pasal 1 , baik secara langsung atau tidak langsung untuk menjalankan usaha menurut atau berdasarkan ketentuanketentuan Undang- Undang ini.

\section{Teori-Teori Investasi \\ Teori Harrod-Domar}

Teori Harrod - Domar adalah perkembangan langsung dari teori makro Keynes jangka pendek yang dianggap kurang lengkap karena tidak menyinggung persoalan mengatasi masalah-masalah ekonomi makro jangka panjang. Harrod - Domar dalam teorinya tetap mengikuti pendapat para ahli ekonomi terdahulu yang menekankan pembentukan modal dalam menciptakan pertumbuhan ekonomi. Dimana teori Keynes mengabaikan peranan pembentukan modal sebagai pengeluaran yang mempertinggi kesanggupan sektor perusahaan untuk menghasilkan barang-barang yang diperlukan masyarakat, analisis Keynes lebih ditekankan kepada masalah kekurangan pengeluaran masyarakat, karena ia menganggap tingkat kegiatan ekonomi ditentukan oleh tingkat pengeluaran seluruh masyarakat bukan kepada kesanggupan barang-barang modal untuk memproduksi barang-barang.

Teori pertumbuhan Ekonomi dari Harrod - Domar memperhatikan kedua fungsi dalam pembentukan modal tersebut dalam kegiatan ekonomi, menerangkan bahwa pembentukan modal dipandang sebagai pengeluaran yang akan menambah kesanggupan suatu perekonomian untuk menghasilkan barang maupun sebagai pengeluaran yang akan menambah permintaan efektif seluruh masyarakat.

\section{Teori Robert Solow}

Menurut Robert Solow faktor-faktor yang mempengaruhi pertumbuhan ekonomi diantaranya adalah stok modal, pertumbuhan tenaga kerja, dan perkembangan teknologi. Model Pertumbuhan Solow ini merupakan pengembangan dari formulasi Harrod-Domar dengan menambahkan variabel tenaga kerja, serta memperkenalkan faktor teknologi.

\section{Teori Schumpeter}

Schumpeter berkeyakinan bahwa pembangunan ekonomi terutama diciptakan oleh inisiatif dari golongan pengusaha yang inovatif atau golongan entrepreneur yakni golongan orang-orang yang yang mengkoordinasi faktor-faktor produksi lainnya untuk menciptakan barang yang diperlukan masyarakat. Mereka adalah orang-orang yang melakukan pembaharuan dalam masyarakat. Kegiatan ini akan mempertinggi pendapatan dan menaikkan tingkat konsumsi masyarakat. Kenaikan tersebut akan mendorong perusahaan-perusahaan lain untuk memperbesar tingkat produksinya dan akhirnya akan mengadakan penanaman modal baru.

\section{Belanja Daerah}

Pendapatan Asli Daerah maupun dari dana perimbangan digunakan oleh pemerintah daerah untuk membiayai belanja daerah. Belanja daerah itu sendiri menurut UU No. 32 Tahun 2004 tentang Pemerintah Daerah, belanja daerah adalah semua kewajiban daerah yang diakui sebagai pengurang nilai kekayaan bersih dalam periode anggaran yang bersangkutan. Peraturan Menteri Dalam Negeri Nomor 13 Tahun 2006 tentang Pedoman Pengelolaan Keuangan Daerah pasal 31 ayat (1) menyebutkan bahwa belanja daerah dipergunakan dalam rangka mendanai pelaksanaan urusan pemerintah yang menjadi kewenangan provinsi atau kabupeten/kota yang terdiri dari urusan wajib, urusan pilihan dan urusan yang penanganannya dalam bagian atau bidang tertentu yang dapat dilaksanakan bersama antara pemerintah dan pemerintah daerah atau antar pemerintah daerah yang ditetapkan berdasarkan peraturan perundangundangan. 
Teori-Teori Pengeluaran Pemerintah

Pengeluaran pemerintah adalah konsumsi barang dan jasa yang dilakukan pemerintah serta pembiayaan yang dilakukan pemerintah untuk keperluan administrasi pemerintahan dan kegiatankegiatan pembangunan (Sukirno, 2002). Pemerintah tentu saja tidak hanya melakukan pengeluaran, tetapi juga memperoleh penerimaan. Pengeluaran pemerintah biasanya direncanakan jauh lebih dulu. Jadi pemerintah membuat daftar anggaran yang akan dikeluarkan setiap tahun nya, yang di Indonesia dijabarkan dalam Anggaran Perencanaan Belanja Negara (APBN). Penerimaan dan pengeluaran pemerintah dimasukkan dalam suatu konsep terpadu mengenai pendapatan dan belanja negara.

\section{Teori Keynes}

Persamaan keseimbangan pendapatan nasional menurut Keynes adalah $\mathrm{Y}=\mathrm{C}+\mathrm{I}+\mathrm{G}$. Dimana; $\mathrm{C}=$ Konsumsi (consumtion); $\mathrm{G}=$ Pengeluaran pemerintah (Government expenditures); I= Investasi (investment).

Dengan membandingkan nilai $(G)$ terhadap $Y$ serta mengamati dari waktu ke waktu dapat diketahui seberapa besar kontribusi pengeluaran pemerintah dalam pembentukan pendapatan nasional. Menurut Keynes, untuk menghindari timbulnya stagnasi dalam perekonomian, pemerintah berupaya untuk meningkatkan jumlah pengeluaran pemerintah (G) dengan tingkat yang lebih tinggi dari pendapatan nasional, sehingga dapat mengimbangi kecenderungan mengkonsumsi $(\mathrm{C})$ dalam perekonomian. Dengan ini, juga dapat dianalisis seberapa penting peranan pemerintah dalam perekonomian nasional.

\section{Teori Adolf Wagner}

Adolf Wagner menyatakan bahwa pengeluaran pemerintah dan kegiatan pemerintah semakin lama semakin meningkat. Tendensi ini oleh Wagner dise- but dengan hukum selalu meningkatnya peranan pemerintah. Inti teorinya yaitu makin meningkatnya peran pemerintah dalam kegiatan dan kehidupan ekonomi masyarakat sebagai suatu keseluruhan. Wagner menyatakan bahwa dalam suatu perekonomian apabila pendapatan per kapita meningkat maka secara relatif pengeluaran pemerintah pun akan meningkat terutama disebabkan karena pemerintah harus mengatur hubungan yang timbul dalam masyarakat, hukum, pendidikan, rekreasi, kebudayaan dan sebagainya (Nkiru, 2013).

Wihda (2014) dalam penelitiannya yang mengambil kasus penanaman modal dalam negeri terhadap partumbuhan ekonomi. Penelitiannya menyatakan PMDN tidak berpengaruh signifikan terhadap pertumbuhan ekonomi sebaliknya pengeluaran pemerintah dalam penelitiannya berpengaruh positif terhadap pertumbuhan ekonomi di D.I.Y Yogyakarta.

Penelitian yang dilakukan oleh Mokodompis (2014) yang mengambil kasus penanaman modal asing terhadap pertumbuhan ekonomi. Menurut Mokodampis Penanaman Modal Asing (PMA) di Kota Manado berpengaruh negatif dan mempunyai hubungan yang tidak signifikan terhadap pertumbuhan ekonomi Kota Manado. Hal tersebut disebabkan karena pengembangan Penanaman Modal Asing (PMA) di Kota Manado masih terhambat oleh rumitnya pengurusan perijinan akibat birokrasi yang berbelit-belit serta kurangnya keterpaduan koordinasi antar departemen yang terkait, kurang tersedianya fasilitas pendukung seperti transportasi, tenaga kerja terampil, dan teknologi. Sehingga investor asing kurang berminat untuk menanamkan modalnya di Kota Manado.

\section{Metode Penelitian}

Jenis penelitian yang digunakan dalam penelitian ini adalah penelitian kuantitatif. Dimana dalam penelitian ini peneliti ingin mengetahui tentang PMDN, 
PMA, belanja daerah di Jawa Timur dan pertumbuhan ekonomi Kota Surabaya dan Kabupaten Banyuwangi selama tahun 2001 sampai tahun 2014. Analisis data dilakukan dengan menguji secara statistis terhadap variabel-variabel yang telah dikumpulkan dengan bantuan program EViews 8.

Sumber data merupakan asal, tempat atau lokasi data peneliti. Sumber data penelitian ini diperoleh dari sumber data sekunder yaitu sumber data yang diperoleh dari pihak di luar sasaran penelitian. Data penelitian ini diambil dari Badan Pusat Statistika, Badan Penanaman Modal, Badan Keuangan dan Pengelolaan Aset Daerah dan institusi daerah terkait, jurnal, artikel, dan media online yang relevan. Data yang digunakan merupakan data time series 2000-2014.

Rancangan penelitian ini dapat dijelaskan dengan gambar sebagai berikut : artikel, dan media online yang relevan.

Teknik penganalisisan yang peneliti gunakan dalam penelitian ini adalah teknik analisis regresi linier berganda. Hubungan antara variabel ditentukan sebagai berikut:

$$
\mathrm{Y}=\mathrm{a}+\mathrm{b}_{1} \mathrm{x}_{1}+\mathrm{b}_{2} \mathrm{x}_{1}+\mathrm{b}_{3} \mathrm{x}_{3}+\mathrm{e}_{\mathrm{i}}
$$

Keterangan; $Y=$ Pertumbuhan Ekonomi; $\mathrm{a}=$ Konstanta persamaan regresi; b1= Koefisien regresi untuk X1; b2= Koefisien regresi untuk $\mathrm{X} 2$; $\mathrm{X} 1=\mathrm{PMA}$; $\mathrm{X} 2=$ PMDN;X3= Belanja Daerah; e $=$ Standart error.

\section{Hasil dan Pembahasan \\ Perkembangan Penanaman Modal \\ Dalam Negeri Di Jawa Timur}

Pada tahun 2001 PMDN Jawa

Timur sebesar Rp. 690.831.000.000 dan pada tahun 2002 perkembangan PMDN Jawa Timur meningkat menjadi Rp. 813.441.000.000 diakibatkan karena

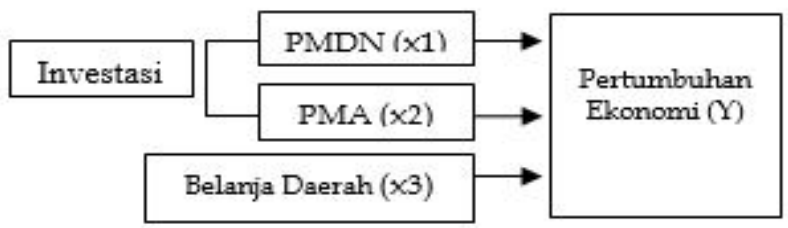

Gambar 1.

Rancangan Penelitian

Populasi dari penelitian ini adalah penanaman modal dalam negeri (PMDN), penanaman modal asing (PMA), belanja daerah Provinsi Jawa Timur, serta pertumbuhan ekonomi Kota Surabaya dan Kabupaten Banyuwangi. Sampel penelitian ini adalah penanaman modal dalam negeri (PMDN), penanaman modal asing (PMA), belanja daerah Provinsi Jawa Timur, serta pertumbuhan ekonomi Kota Surabaya dan Kabupaten Banyuwangi pada tahun 20012014.

Teknik pengumpulan data dalam penelitian ini adalah dokumentasi yang diperoleh melalui sumber data Badan Pusat Statistika, Badan Penanaman Modal, Badan Keuangan dan Pengelolaan Aset Daerah dan institusi daerah terkait, jurnal, menguatnya nilai tukar rupiah. Hal ini terus berlanjut sampai tahun 2005, dimana nilai PMDN jawa Timur selalu mengalami peningkatan yang signifikan yaitu 1.553.224.000.000 di tahun 2003, Rp.4.055.266.000.000 di tahun 2004 dan Rp.5.516.851.000.000 di tahun 2005. Pada tahun 2006 PMDN Jawa Timur juga mengalami kenaikan yang sangat tinggi yaitu sebesar 2935.09\% dengan nilai PMDN sebesar Rp. 167.441.529.000.000 keberhasilan dalam peningkatan PMDN ini tersebut menunjukkan membaiknya sektor riil dan adanya kepercayaan investor terhadap Jawa Timur. Pada tahun 2007 PMDN mengalami penurunan $90.02 \%$ dari nilai PMDN tahun sebelumnya yaitu Rp. 167.441.529.000.000 menjadi 
Rp. 16.705.091.000.000 di tahun 2007. Hal tersebut berkaitan dengan adanya bencana lumpur lapindo di Kabupaten Sidoarjo, dimana bencana ini memberikan pengaruh besar terhadap perkembangan perekonomian di Jawa Timur. Namun pada tahun 2008 sampai 2010 PMDN Jawa Timur mengalami kenaikan yang signifikan setiap tahunnya. Yaitu 19,20\% di tahun 2008, 27,58\% di tahun 2009 dan $61,42 \%$ di tahun 2010. Pada tahun 2008 terjadi krisis global yang mempengaruhi perekonomian dunia termasuk Indonesia khususnya Provinsi Jawa Timur. Namun investor dalam negeri Jawa Timur tidak terpengaruh adanya krisis global. Hal ini terlihat dari peningkatan nilai PMDN dari Rp. 16.705.091.000.000 di tahun 2007 menjadi Rp. 19.912.810.000.000 di tahun 2008. Pada tahun 2009 dan 2010 PMDN mengalami kenaikan kenaikan masingmasing sebesar $27.58 \%$ di tahun 2009 dan $61,42 \%$ di tahun 2010 .

Hal tersebut menunjukkan semakin tumbuhnya kepercayaan investor untuk menanamkan modalnya di Jawa Timur. Selain itu di tahun 2009 juga telah diresmikan jembatan suramadu yang merupakan jembatan penghubung antara pulau Jawa dan pulau Madura. Adanya jembatan suramadu ini merupakan salah satu faktor pendorong tersendiri bagi perkembangan investasi di Jawa Timur. Selama periode tahun 2007 sampai tahun 2010 investasi. PMDN yang ada di Jawa Timur selalu mengalami kenaikan. Namun pada tahun 2011 investasi PMDN turun sebesar Rp. 14.769.842.000.000 dari Rp.41.009.463.000.000 pada tahun 2010 menjadi Rp. 26.239.621.000.000 pada tahun 2011. Lalu PMDN Naik kembali menjadi Rp. 46.310.912.000.000 pada tahun 2012. Pada tahun 2013 dan 2014 kembali mengalami penurunan berturut-turut menjadi Rp. 3.895.446.000.000 pada tahun 2013, hal ini dikarenakan adanya kenaikan harga BBM (Bahan Bakar Minyak) bersubsidi pada bulan juni yang berimbas pada penurunan PMDN di tahun yang sama. Pada tahun 2014 PMDN Jawa Timur juga mengalami penurunan menjadi Rp. 35.724.063.000.000.

Data belanja pemerintah yang bersumber dari Biro Keuangan Gubernur Jawa Timur menunjukkan belanja pemerintah di Provinsi Jawa Timur pada rentang waktu tahun 2001-2015 selalu naik setiap tahunnya, kecuali pada tahun 2004 dimana belanja daerah pada tahun tersebut sebesar Rp. 3.516.027.000.000 turun sebesar Rp. 16.931.000.000 dari tahun 2003 yang sebesar Rp. 3.532.958.000.000. Selain itu belanja daerah ditahun selanjutnya selalu mengalami kenaikan. Belanja pemerintah Jawa Timur untuk tahun terakhir 2014 sebesar Rp. 20.027.647.000.000 dan belanja pemerintah Jawa Timur di Tahun 2015 sebesar Rp. 23.720.919.000.000 naik sebesar Rp. 22.868.758.000.000 dibandingkan dengan tahun 2000 yang hanya sebesar Rp. 852.161.000.000.

\section{Hasil Penelitian \\ Uji Regresi Data Panel}

Dalam menentukan teknik mana yang paling tepat, maka harus dilakukan pengujian. Pertama uji Chow digunakan untuk memilih antara Common Effect atau Fixed Effect. Kedua, uji Langrange Multiplier (LM) digunakan untuk memilih antara Common Effect atau Random Effect. Terakhir, untuk memilih antara Fixed Effect atau Random Effect digunakan uji yang dikemukakan oleh Hausman. Akan tetapi, syarat pengujiannya dapat dilakukan bila objek data silang lebih besar dari koefisien atau variabelnya (Baltagi, 2005).

Setelah menentukan secara tepat spesifikasi model yang akan digunakan, menggunakan uji chow. Maka diperoleh metode analisis yang paling tepat digunakan dalam penelitian ini adalah analisis regresi data panel dengan model common effect dengan bantuan EViews 8.0. Pemilihan model analisis data panel berhenti di uji chow, karena objek data silang tidak 
lebih besar dari koefisien atau variabelnya sehingga tidak perlu melakukan uji Langrange Multiplier (LM). Berdasarkan data yang diolah, maka diperoleh persamaan regresi data panel sebagai berikut:

$\mathrm{PE}=3.99390454602+5.92950002774 \mathrm{e}-$ 09*PMDN - 7.30231116808e-08*PMA + $2.09720436579 \mathrm{e}-07^{*} \mathrm{BD}$

Persamaan regresi data panel menunjukkan bahwa: (a) Nilai konstanta sebesar 3.99390454602 menunjukkan bahwa jika nilai PMDN, PMA dan belanja daerah nol maka pertumbuhan ekonomi sebesar 3.99390454602; (b) $\mathrm{PMDN}=$ 5.92950002774e-09 artinya jika variabel PMDN bertambah $1 \%$, sedangkan variabel PMA dan belanja daerah tetap maka pertumbuhan ekonomi akan mengalami peningkatan sebesar 592,95\%. Tanda positif (+) menunjukkan adanya hubungan yang searah antara PMDN dengan pertumbuhan ekonomi. Jika PMDN tinggi maka pertumbuhan ekonomi juga tinggi; (c) PMA= -7.30231116808e-08 artinya jika variabel PMA bertambah $1 \%$, sedangkan variabel PMDN dan belanja daerah tetap maka pertumbuhan ekonomi akan mengalami penurunan sebesar $730,23 \%$. Tanda negatif (-) menunjukkan adanya hubungan yang tidak searah antara PMA dengan pertumbuhan ekonomi. Jika PMA tinggi maka pertumbuhan ekonomi juga tinggi; (d) Belanja Daerah $=2.09720436579 \mathrm{e}-07$ artinya jika variable Belanja Daerah bertambah $1 \%$, sedangkan variabel PMDN dan PMA tetap maka pertumbuhan ekonomi akan mengalami peningkatan sebesar $209.72 \%$. Tanda positif (+) menunjukkan adanya hubungan yang searah antara belanja daerah dengan pertumbuhan ekonomi. Jika belanja daerah tinggi maka pertumbuhan ekonomi juga tinggi.

\section{Uji Hipotesis}

Uji Signifikansi Individu (uji t)

Uji t digunakan untuk mengetahui ada tidaknya pengaruh masing-masing variabel independen secara parsial (individual) terhadap variabel dependen yang diuji pada tingkat signifikasi 0,05 .

1) Uji t terhadap PMDN

Dari hasil uji t bahwa PMDN berpengaruh positif terhadap pertumbuhan ekonomi Kota Surabaya dan Kabupaten Banyuwangi. Hal itu ditunjukan oleh nilai koefisien PMDN bernilai 5.93. Arti dari besaran koefisien itu adalah apabila PMDN naik $1 \%$ maka pertumbuhan ekonomi naik sebesar $5.93 \%$. Selain itu nilai probabilitas yang dimiliki PMDN adalah 0.1389 atau lebih besar dari $\alpha(0,05)$, hal ini menunjukan bahwa PMDN tidak berpengaruh signifikan terhadap pertumbuhan ekonomi Kota Surabaya dan Kabupaten Banyuwangi.

\section{2) Uji t terhadap PMA}

Dari hasil uji t bahwa PMA berpengaruh negatif terhadap pertumbuhan ekonomi Kota Surabaya dan Kabupaten Banyuwangi. Hal itu ditunjukan oleh nilai koefisien PMA sebesar -7.30 Arti dari besaran koefisien itu adalah apabila PMA naik $1 \%$ maka pertumbuhan ekonomi turun sebesar $7.30 \%$. Selain itu nilai probabilitas yang dimiliki PMA adalah 0.6313 atau lebih besar dari $\alpha$ $(0,05)$, hal ini menunjukan bahwa PMA tidak berpengaruh signifikan terhadap pertumbuhan ekonomi Kota Surabaya dan Kabupaten Banyuwangi.

3) Uji t terhadap belanja daerah

Dari hasil uji t bahwa belanja daerah berpengaruh positif terhadap pertumbuhan ekonomi Kota Surabaya dan Kabupaten Banyuwangi. Hal itu ditunjukan oleh nilai koefisien belanja daerah sebesar 2.10. Arti dari besaran koefisien itu adalah apabila belanja daerah naik 1\% maka pertumbuhan ekonomi turun sebesar $2.10 \%$. Selain itu nilai probabilitas yang dimiliki belanja daerah adalah 0.0042 atau lebih kecil 
dari $\alpha(0,05)$, hal ini menunjukan bahwa belanja daerah berpengaruh signifikan terhadap pertumbuhan ekonomi Kota Surabaya dan Kabupaten Banyuwangi.

\section{Uji Signifikansi Simultan (uji F)}

Uji $F$ dilakukan dengan tujuan menguji apakah semua variabel independen yang dimasukkan dalam model mempunyai pengaruh secara bersama-sama terhadap variabel dependen. Dari hasil uji $F$ diperoleh nilai probablitas untuk $F$ sebesar $0.0000006<0.05$ jadi kesimpulannya PMDN, PMA dan belanja daerah bersamasama berpengaruh signifikan terhadap pertumbuhan ekonomi Kota Surabaya dan Kabupaten Banyuwangi.

\section{Koefisien determinasi (R2)}

Dari hasil uji R2 diperoleh nilai koefisien determinasi sebesar 0.666083 . Hal ini menunjukkan $66.61 \%$ peningkatan pertumbuhan ekonomi Kota Surabaya dan Kabupaten Banyuwangi dipengaruhi oleh PMDN, PMA dan belanja daerah, sedangkan sisanya sebesar $33.39 \%$ dijelaskan oleh faktor lain yang tidak diteliti dalam penelitian ini.

\section{Pengaruh Penanaman Modal Dalam Negeri (Pmdn) Jawa Timur Terha- dap Pertumbuhan Ekonomi Di Kota Surabaya Dan Kabupaten Banyuwangi} Variabel PMDN Jawa Timur tidak mempunyai pengaruh terhadap pertumbuhan ekonomi Kota Surabaya dan Kabupaten Banyuwangi. Hasil temuan diatas sesuai dengan pendapat Keynes, yang menyatakan tingkat kegiatan ekonomi tidak ditentukan oleh pembentukan modal, bahkan peran investasi atau pembentukan modal dalam teorinya diabaikan sama sekali. Dalam analisisnya Keynes lebih menekankan kebijakan fiskal. la beranggapan dengan kebijakan fiskal pemerintah dianggap bisa mempengaruhi jalannya perekonomian. Langkah itu dilakukan dengan menyuntikkan dana berupa pengeluaran pemerintah untuk proyek-proyek yang mampu menyerap tenaga kerja.

Kurangnya kepercayaan investor diakibatkan oleh komunikasi antara pengusaha dan pemerintah yang masih kurang baik dan tata kelola infrastruktur. Dimana sarana dan prasarana merupakan salah satu faktor.

Buruknya kualitas jalan kabupaten di wilayah Banyuwangi dapat terlihat dari akses darat yang menghubungkan wilayah Banyuwangi dengan wilayah lainnya hanya terdiri dari dua akses yatu jalur pantura (jalur pantai utara melewati Kabupaten Situbondo dan Bondowoso) dan jalur Banyuwangi-Jember dimana harus melewati Gunung Gumitir yang merupakan jalur curam dengan jalan yang berkelok-kelok tajam. Tak heran dijalur Gunung Gumitir ini sering terjadi kecelakan sepeda motor bahkan truk besar yang menyebabkan terjadinya kemacetan ber jamjam sehingga mengganggu arus transportasi.

Begitu pula dengan Kota Surabaya, masalah sarana dan prasarana jalan di Kota Surabaya terlihat dari adanya kemacetan di pusat perekonomian utama. Serta adanya bencana lumpur lapindo yang jika musim penghujan luapan akan menggenangi bahkan membanjiri jalur penghubung porong-surabaya dan jalur kereta api yang akan mengganggu arus transportasi. Padahal jalur ini merupakan salah satu akses untuk menuju Surabaya. Hal ini mengakibatkan biaya transportasi yang tinggi dan tingkat pengembalian investasi yang lebih rendah.

Seperti yang dikemukakan (Cahyono, Subroto, and Anwar 2017) perbedaan kondisi infrastruktur serta sumberdaya fisik dan non fisik akhinya akan membentuk perbedaan potensi dari masing-masing daerah. Tentunya ini akan berdampak pada investasi yang akan ditanamkan pada suatu daerah. Perbaikan infrastruktur akan memberikan dampak pada semakin rendahnya biaya ekonomi 
yang ditimbulkan oleh masalah fisik dalam hal ini adalah transportasi.

\section{Pengaruh Belanja Daerah Terhadap Pertumbuhan Ekonomi Jawa Timur} Kemampuan Anggaran Pendapatan dan Belanja Daerah (APBD) Kota Surabaya dari tahun ke tahun menimbulkan berbagai perubahan-perubahan dalam hal potensi-potensi unggulan dalam bidang. Begitu pula dengan kemampuan APBD Kabupaten Banyuwangi yang terus meningkat dari tahun ke tahun. Hal ini menjadikan belanja pemerintah $\mathrm{Ka}$ bupaten Banyuwangi juga turut menggerakkan perekonomian. Jika pada 2010, APBD baru Rp 1,29 triliun, maka tahun 2015 lalu menembus angka Rp 3 triliun. Terjadi peningkatan APBD sebesar 133 persen dari 2010 ke 2015, yang secara kumulatif tumbuh 171,43 persen dari 2010 ke 2015 atau rata-rata 34,28 persen pertahun. Lebih tinggi dari nasional yang hanya di kisaran 15 persen pertahun (banyuwangikab.go.id). Keberhasilan mengatur anggaran belanja daerah (APBD) di Kota Surabaya dan Kabupaten Banyuwangi dapat terlihat dari rata-rata pertumbuhan ekonomi Kota Surabaya tahun 2010-2014 lebih tinggi dari Jawa Timur. Kondisi diatas sesuai dengan teori dari Adolf Wagner yang menyatakan bahwa pengeluaran pemerintah dan kegiatan pemerintah semakin lama semakin meningkat.

Belanja daerah ini juga terkait dengan kondisi fiskal masing-masing daerah. Sebagaimana seperti yang dikemukakan (Permatasari et al. 2013), bahwa salah satu penyebab rendahnya pertumbuhan dan kontribusi sektor riil adalah kebijakan ekonomi, baik fiskal dan moneter yang kurang mendukung pelaku ekonomi di sektor riil. Penggunaan belanja daerah harus cermat pemanfaatannya. Jangan sampai belanja daerah hanya habis untuk belanja rutin saja. Akselerasi dari laju pertumbuhan ekonomi daerah juga ditentukan oleh kapasitas belanja daerah yang pe- runtukannya bagi pengembangan potensi daerah.

\section{Pengaruh Belanja Daerah Dan Pmdn Terhadap Pertumbuhan Ekonomi Jawa Timur}

PMDN, PMA dan belanja daerah bersama-sama berpengaruh signifikan terhadap pertumbuhan ekonomi Kota Surabaya dan Kabupaten Banyuwangi. Hal ini dikarenakan sejak beberapa tahun ini dilakukan kebijakan-kebijakan oleh pemerintah Kota Surabaya dan Kabupaten Banyuwangi dibidang investasi dan belanja daerah. Sehingga terdapat pengaruh yang baik terhadap penanaman modal di Jawa Timur baik PMDN maupun PMA.

Kebijakan penanaman modal pemerintah Kota Surabaya melalui Badan Koordinasi Pelayanan dan Penanaman Modal (BKPPM) Kota Surabaya dan Badan Pelayanan Perizinan Terpadu (BP2T) di Kabupaten Banyuwangi yang sejak tahun 2010 mulai Pro-Investasi, dengan insentif \& pajak yang menarik serta didukung oleh pemerintah yang responsive dapat menarik kepercayaan investor.

Peningkatan kapasitas pelabuhan Tanjung Perak di Surabaya, pelabuhan Tanjungwangi di Banyuwangi, penambahan runway Bandara Internasional Juanda, mempercepat pembangunan jalan tol pengganti di wilayah porong Sidoarjo, pembangunan beberapa jalan baru seperti MERR di Surabaya, pembangunan jalur alternative Banyuwangi yang melewati Glenmor sehingga tidak harus melewati Gunung Gumitir yang rawan kecelakaan serta peroperasionalan bandara blimbingsari di Banyuwangi. Akses jalan baru ini yang akhirnya dapat menimbulkan kepercayaan investor untuk melakukan investasi di Surabaya dan Banyuwangi.

Pemerintah Surabaya terus membangun jalur transportasi yang memadai, termasuk membangun jalan-jalan baru, seperti frontage road, dan Jalur Lingkar Luar Timur (JLLT) dan Jalur Lingkar Luar 
Barat (JLLB). Semua pembangunan itu untuk mendorong kenyamanan investasi. Dinas juga berupaya menciptakan Surabaya bebas dari banjir meski secara topografi, Surabaya di pesisir sehingga sulit untuk bebas dari banjir. Akan tetapi, beberapa kawasan yang sebelumnya menjadi langganan banjir, saat ini sudah mulai menurun.

Pemerintah Kota Surabaya dan Kabupaten Banyuwangi juga turut melaksanakan inovasi-inovasi promosi daerah melalui pameran budaya dan event-event nasional maupun internasional guna memperkenalkan daerah serta menggambarkan bahwa daerah siap menerima investasi baru. Event tersebut antara lain Banyuwangi Ethno Carnival (BEC), International Tour de ljen, Festival Gandrung Sewu, Banyuwangi Beach Jazz Festival, event Banyuwangi International BMX dll, lalu di Surabaya adanya festival dan beragam kegiatan seperti Surabaya Fashion Parade, Festival rujak uleg, Surabaya urban culture festival, Parade budaya, pawai bunga, seminar-seminar bertaraf internasional menjadikan Kota dan Kabupaten ini dikenal oleh masyarakat mancanegara. Inovasi-inovasi promosi daerah tersebut dimaksudkan untuk menarik investor yang dilakukan oleh Kota Surabaya dan Kabupaten Banyuwangi. Kegiatan promosi investasi Kota Surabaya dan Kabupaten Banyuwangi untuk mengenalkan daerahnya tidaklah sia-sia itu terlihat dari diterimanya penganugerahan Investment Award kategori promosi investasi dari Gubernur Jawa Timur tahun 2013, dimana Kabupaten Banyuwangi menduduki peringkat pertama dan Kota Surabaya mendapatkan peringkat kedua karena dinilai paling baik dalam melakukan promosi investasi dari kabupaten/kota se Jatim. Begitu pula dengan kemampuan APBD Kota Surabaya dan Kabupaten Banyuwangi dari tahun ke tahun menimbulkan berbagai perubahanperubahan dalam hal potensi-potensi unggulan dalam bidang. Dilain pihak melihat pertumbuhan ekonomi Kota Surabaya dan Kabupaten yang lebih tinggi daripada Jawa Timur, menjelaskan bahwa APBD Kota Surabaya dan Kabupaten Banyuwangi bersifat meningkatkan produktivitas, dan berjalan secara efisien dan efektif.

Menurut (Cahyono et al. 2016), berkaitan dengan pembangunan ekonomi regional, kebijakan pemerintah provinsi akan berpengarah terhadap perekonomian daerah yag lebih kecil seperti kabupaten/ kota. Dalam hal ini tak terkecuali kota Surabaya dan kabupaten Banyuwangi. Apabila PMDN danPMAbisa sesuai dengan kebutuhan dan potensi daerah maka tidak mungkin laju pertumbuhan ekonomi akan semakin cepat. Peran PMDN, PMA dan belanja daerah Jawa Timur terhadap pertumbuhan ekonomi Kota Surabaya dan Kabupaten Banyuwangi sangat baik, terlihat dari rata-rata pertumbuhan ekonomi Kota Surabaya tahun 2010-2014 lebih tinggi dari Jawa Timur. Pertumbuhan ekonomi Kota Surabaya tahun 2010-2014 sebesar 7,18 persen, sedangkan Jatim hanya 6,71 persen. Begitu juga dengan pertumbuhan ekonomi Kabupaten Banyuwangi yang dalam 5 tahun terakhir rata-rata pertumbuhan ekonomi Kabupaten Banyuwangi lebih tinggi dari Jawa Timur, dimana pertumbuhan Banyuwangi 2010-2014 sebesar 6,87 persen, sedangkan Jatim hanya 6,71 persen.

\section{Penutup}

Dari serangkaian pembahasan tentang pengaruh PMDN, PMA dan belanja daerah Jawa Timur terhadap pertumbuhan ekonomi di Kota Surabaya dan Kabupaten Banyuwangi dengan proses pengelolaan data dengan metode kuantitatif, maka dapat ditarik kesimpulan sebagai berikut : (1) Penanaman modal dalam negeri Jawa Timur tidak berpengaruh terhadap pertumbuhan ekonomi Kota Surabaya dan Kabupaten Banyuwangi; (2) Penanaman modal asing Jawa Timur tidak berpengaruh pertumbuhan ekonomi Kota Surabaya 
dan Kabupaten Banyuwangi; (3) Belanja daerah Jawa Timur berpengaruh terhadap pertumbuhan ekonomi Kota Surabaya dan Kabupaten Banyuwangi; (4) Penanaman modal dalam negeri, penanaman modal asing dan belanja daerah secara simultan atau bersama-sama berpengaruh signifikan terhadap pertumbuhan ekonomi Kota Surabaya dan Kabupaten Banyuwangi.

Dari hasil analisis diatas maka saran yang diberikan sebagai berikut: (1) Dalam meningkatkan penanaman modal pemerintah Provinsi Jawa Timur harus memperbaiki sarana dan prasarana penunjang dalam peningkatan penanaman modal seperti akses transportasi antar wilayah di Jawa Timur guna menekan biaya distribusi yang pada akhirnya akan mengefektifkan perekonomian; (2) Pemerintah Kota Surabaya dan Kabupaten Banyuwangi harus meningkatkan kebijakan yang dapat meningkatkan kuantitas penanaman modal, terutama kebijakan di sektor industri dan perdagangan, karena sektor ini merupakan penanaman modal yang tinggi di Kota Surabaya dan Kabupaten Banyuwangi; (3) Pemerintah Kota Surabaya dan Kabupaten Banyuwangi harus lebih mengalokasikan anggaran belanja daerah ke belanja pembangunan atau belanja publik seperti membiayai proyek-proyek infrastruktur sehingga dapat meningkatkan pengembangan ekonomi diberbagai sektor; (4) Pemerintah Kota Surabaya dan Kabupaten Banyuwangi harus lebih mengalokasikan anggaran belanja daerah ke belanja langsung (belanja barang dan jasa, serta belanja modal) yang sifatnya menambah aset-aset dan mengoptimalkan sumberdaya dan potensi yang ada didaerahnya guna mendapatkan penerimaan yang besar.

\section{Daftar Pustaka}

Adisasmita, R. 2013. Teori-Teori Pembangunan Ekonomi, Pertumbuhan Ekonomi dan Pertumbuhan Wilayah. Graha
IImu. Yogyakarta.

Badan Pusat Statistik. Jawa Timur Dalam Angka. Jakarta.

Badrudin, Rudy. 2012. Ekonomika Otonomi Daerah. UPP STIM YKPN.S. Yogyakarta.

Cahyono Hendry. etc. 2017. Income Disparity in Gerbangkertosusila Area of East Java Indonesia. International Journal of Economics and Financiallssues. 7 (1): 14-18.

Cahyono Hendry. etc. 2016. Analysis Of The Potential Economic Sector In The Southern Of East Java Indonesia. International Journal of Economic Research. 13 (2): 2663-80.

Deliarnov. 2010. Perkembangan Pemikiran Ekonomi. Raja Grafindo Persada. Jakarta.

Mangkoesoebroto, Guritno. 2008. Ekonomi Publik. BPFE UGM. Yogyakarta.

Nachrowi. dan Hardius Usman. 2006. Ekonometrika untuk Analisis Ekonomi dan Keuangan. Fakultas Ekonomi Universitas Indonesia. Jakarta.

Peraturan Menteri Dalam Negeri Nomor 21 Tahun 2011 Tentang Perubahan Kedua Atas Peraturan Menteri Dalam Negeri Nomor 13 Tahun 2006 Tentang Pedoman Pengelolaan Keuangan Daerah.

Peraturan Menteri Dalam Negeri Nomor 13 Tahun 2006 Tentang Pedoman Pengelolaan Keuangan Daerah.

Permatasari, Ika. etc. 2013. The Synergy of Fiscal and Monetary Policy for Real Sector. Journal of Economics, Business, and Accountancy Ventura. 16(3): 373-84.

Rosyidi, Suherman. 2011. Pengantar Teori Ekonomi (Pendekatan Kepada Teori Ekonomi Mikro Dan Makro). Raja Grafindo Persada. Jakarta. 
Sinambela, Lijan Poltak. 2004. Metode Penelitian Kuntitatif. Graha IImu. Yogyakarta.

Sugiyono. 2012. Metode Penelitian Kuantitatif Kualitatif dan R\&B. Alfabeta. Bandung.

Suliyanto. 2011. Ekonomika Terapan Teori dan Aplikasi Dengan SPSS. ANDI Yogyakarta. Yogyakarta.

Todaro, Michael. dan Smith Stephen. 2002. Pembangunan Ekonomi. Erlangga. Jakarta.

Undang-Undang Nomor 11 Tahun 1970 Tentang Perubahan Dan Tambahan Undang-Undang No. 1 Tahun 1967 Tentang Penanaman Modal Asing.

Undang-Undang Republik Indonesia. Nomor 12 Tahun 1970 Tentang Perubahan Dan Tambahan Undang-Undang Nomor 6 Tahun 1968 Tentang Penanaman Modal Dalam Negeri.

Winarno, Wing Wahyu. 2009. Analisis Ekonometrika dan Statistika dengan Eviews. Unit Penerbit dan Percetakan Sekolah Tinggi Ilmu Manajemen. Yogyakarta. 